\title{
Root-fungal associations in plants from home gardens of Tripura, Northeast India
}

\author{
Kripamoy Chakraborty ${ }^{1}$, Atithi Debnath ${ }^{1}$, Aparajita Roy Das ${ }^{2}$, Ajay Krishna Saha ${ }^{2}$, Panna Das ${ }^{1 *}$ \\ ${ }^{1}$ Microbiology Laboratory, Department of Botany, Tripura University, Suryamaninagar-799022, Tripura, India. \\ ${ }^{2}$ Mycology and Plant Pathology Laboratory, Department of Botany, Tripura University, Suryamaninagar-799022, India.
}

\section{ARTICLE INFO \\ Article history: \\ Received on: February 10, 2019 \\ Accepted on: April 20, 2019 \\ Available online: September 10, 2019}

\section{Key words:}

Arbuscular mycorrhizal

fungi, dark septate endophyte,

colonization, terrestrial

ecosystems

\begin{abstract}
Mycorrhizal association is an integral part of terrestrial ecosystems. The present work was focused to examine arbuscular mycorrhiza (AM), dark septate endophyte (DSE) fungal colonization, and the composition of AM fungi from two home gardens of Tripura in Northeast India. The results reveal eight plants commonly occurring in two sites belonging to seven families. Of the eight plants, dual colonization of AM and DSE fungi was observed in seven plants from two sites. A total of 18 AM fungal species were recovered from both the sites. The study reveals a robust composition of AM fungi in the home garden ecosystem. AM fungi isolated from these ecosystems confirm their occurrence and these fungi may be beneficial in improving the cultivation practices in the home garden systems of the region.
\end{abstract}

\section{INTRODUCTION}

Arbuscular mycorrhiza (AM) have a symbiotic association between soil fungi of the phylum Glomeromycota [1] and plant roots, which is ubiquitous in the terrestrial ecosystem [2]. It is generally accepted that AM fungi can help in the uptake of plant nutrient like phosphate [3], defend plants against various types of stress [4,5], and decrease the damage caused by root pathogens [6].

There are a group of fungi belonging to ascomycetes called the dark septate endophyte (DSE) fungi that colonize root tissues intracellularly and intercellularly [7] and characterized by microsclerotia and septate melanized hyphae [8]. The common occurrence and are likely to function as mycorrhizal fungi suggest that these endophytes are vital components of natural ecosystems that co-colonized with AM fungi in the same host plants $[9,10]$.

Home gardens are considered as one of the oldest subsistence farming systems practiced by rural communities in many parts of the world, consisting of multilayer systems of trees, shrubs,

\footnotetext{
*Corresponding Author

Panna Das, Microbiology Laboratory, Department of Botany,

Tripura University, Suryamaninagar-799022, Tripura, India.

E-mail:pannalld@gmail.com
}

and herbs around homesteads [11,12]. Home gardens are generally multifunctional and play key roles in providing goods and ecosystem services and also provide numerous benefits for sustaining the livelihood of local inhabitants $[13,14]$.

Mycorrhizal fungi have been studied from forest ecosystems in relation to its ecology and diversity [15-17]. Mycorrhizal associations regarding nutrient status, colonization, and diversity have been studied from plantations and agricultural soils [10,1823].

The cultivation of fruits, vegetables and ornamental plants in home gardens has a long tradition in Northeast India, especially among the people residing in the states of Assam, Manipur, Nagaland, Meghalaya, and Tripura. The diversity of AM fungi in home garden along with different land use system in Arunachal Pradesh has been reported recently [24]. The study of mycorrhizal associations in home garden has not been solely concentrated. Moreover, the colonization status by AM and DSE fungi of plants in the home garden is scarce [25]. Therefore, mycorrhizal colonization of commonly occurring plants and the composition of AM fungi from two home gardens was examined. 


\section{MATERIALS AND METHODS}

\subsection{Study sites}

The root of the plants and soil samples were collected from two home gardens of Tripura, Northeast India. The sites considered for this study were Khowai $\left(24^{\circ} 0^{\prime} 52.18^{\prime \prime} \mathrm{N}\right.$; $91^{\circ} 36^{\prime} 48.48^{\prime \prime} \mathrm{E}$; 23 masl) and Amtali $\left(23^{\circ} 46^{\prime} 14.23^{\prime \prime} \mathrm{N} ; 9^{\circ} 15^{\prime} 46.98^{\prime \prime} \mathrm{E} ; 22\right.$ masl). The sampling period of roots of plants and soil was during March-June 2016.

\subsection{Collection of root and soil samples}

The commonly occurring plants were selected for the assessment of AM and DSE symbiosis from both the sites. To assess the colonization in root samples, root from two to three plants of each species was collected and brought to the laboratory. Care was taken in sampling of root samples of plant species that the roots were traced to the target plants. The rhizospheric soil samples were collected at $0-20 \mathrm{~cm}$ depth around each species and approximately $500 \mathrm{~g}$ soil per plant was collected. All the soil samples from each location were combined and collected in polythene bags, tagged, and brought to the laboratory for further analysis.

\subsection{Analysis of soil properties}

Soil moisture was determined by drying $10 \mathrm{~g}$ fresh soil at $100^{\circ} \mathrm{C}$ for 24 hours in a hot-air oven. For $\mathrm{pH}$ and electrical conductivity, $10 \mathrm{~g}$ of soil was dissolved in $50 \mathrm{ml}$ distilled water and stirred for 20 minutes and kept it for overnight. Measurement of the soil $\mathrm{pH}$ and electrical conductivity was done by using a digital $\mathrm{pH}$ and electrical conductivity meter. Soil texture was determined by the soil hydrometric method [26]. Soil organic carbon (\%) was determined [27]. Available phosphorus was estimated [28]. Soil organic carbon and available phosphorus were estimated by spectrophotometer (UV-VIS Biospectrometer, Eppendorf). There is no known history of fertilizer application in these home gardens. However, biodegradable wastes from the kitchen are used sometimes.

\subsection{Preparation of roots and assessment of AM and DSE fungal colonization}

The root samples brought from the home garden were thoroughly washed in tap water and cut into small pieces of approximately 1 $\mathrm{cm}$ in size. Then the root pieces were processed and stained for observation of mycorrhizal colonization [29]. Root segments were then mounted with lactoglycerol on the slide and examined under a compound microscope (Olympus) for various AM and DSE fungal structures. The mycorrhizal structures were also photographed under Olympus CX21i fitted with camera and software, SImage in computer. The quantification of AM fungal colonization was done by the magnified intersection method and DSE fungi were measured together for microsclerotia and septate hyphae. One plant was assessed only for vesicles and aseptate hyphae with the same method [30].

\subsection{Extraction and identification of AM fungi}

Debris was removed from the soil brought from the field taking utmost care so that the soil attached to the litter and debris was not lost by this process. Fifty grams of soil was placed in the sieves of size $2 \mathrm{~mm}-35 \mu$ and processed with tap water using the wet sieving and decanting method [31]. Then the spores were extracted from each sieve to the filter paper by filtering out the water. The spores on the filter paper laid on the $13.5 \mathrm{~cm}$ Petri dish and were counted under the microscope at $100 \times$ magnification. The spores were then picked up with a needle and mounted in polyvinyl alcohol-lactoglycerol on the slide [32]. Then spores were examined using a compound microscope. The identification of AM fungi was done based on morphological characteristics by matching with original descriptions and e-resources available on the website (www.amf-phylogeny.com).

\subsection{Data analysis}

For evaluation of AM fungi from the home gardens, spore density and species richness were measured. Student $t$-test was performed to assess the significance of means for soil chemical properties occurring at two sites. The colonization data were subjected to analysis of variance and the means were separated by Duncan test $(p<0.05)$. All the data were analyzed using the software, Statistica 9.0.

\section{RESULTS}

The list of commonly occurring plants in two sampled sites is provided in Table 1. Eight plants were found growing in both the sites, of which four were fruit plants and four were vegetables belonging to seven families.

The soil $\mathrm{pH}$ was acidic in both the sites and soil from Khowai exhibiting the lower $\mathrm{pH}$. Electrical conductivity, organic carbon, and available phosphorus were significantly $(p<0.05)$ higher in soil from Khowai than Amtali. Soil texture reveals a high amount of sand in Amtali. The texture indicates soil to be loamy sand of both the sites. The soil properties are presented in Table 2.

Table 1: Family and their uses of commonly occurring plants from two home gardens of Tripura.

\begin{tabular}{llllll} 
Plants & Family & Habit & Uses & Flowering time & Fruiting time \\
A. tricolor L. & Amaranthaceae & Shrub & Vegetable & Throughout the year & Throughout the year \\
A. comosus $($ L.) Merr. & Bromeliaceae & Shrub & Fruit & April-May & June-July \\
A. squamosa L. & Annonaceae & Tree & Fruit & April-May & August-November \\
C. annuum L. & Solanaceae & Herb & Vegetable & July-September & August-October \\
C. pepo L. & Cucurbitaceae & Climber & Vegetable & July-September & August-October \\
S. melongena L. & Solanaceae & Herb & Vegetable & July-September & August-October \\
S. pinnata (L. f.) Kurz & Anacardiaceae & Tree & Fruit & March-April & June-December \\
S. cumini (L.) Skeels. & Myrtaceae & Tree & Fruit & February-April & May-June \\
\hline
\end{tabular}


AM fungal structures, viz., aseptate intracellular hyphae, intercellular hyphae, vesicles, and arbuscules were observed in the roots of plants from home garden of two different sites (Fig. 1). DSE fungal colonization was characterized by melanized septate hyphae, microsclerotia and vesicles-like body were observed in the roots of plants from the home garden of two different sites (Fig. 2). The extent of AM and DSE fungal colonization in the studied plants is presented in Table 3. Dual (AM and DSE fungi) colonization was observed in seven plants. The roots of Amaranthus tricolor were attached with the spore-like structure of AM fungi and extraradical aseptate hyphae (Fig. $2 \mathrm{~h}$ and i). However, arbuscule was absent in A. tricolor in both the sites. AM fungal colonization was maximum in Capsicum annuum and lowest in Ananas comosus. DSE fungal colonization was maximum in $A$. tricolor in both the sites and minimum was recorded in Solanum melongena. C. annuum showed the highest percentage of arbuscule and $A$. comosus showed the lowest number of arbuscule.
Root length percentage of a vesicle was maximum in $C$. annuum and minimum in Spondias pinnata.

The significantly $(p<0.05)$ higher spore density was observed in Khowai than Amtali. Out of 18 morphotypes, 14 and 13 were isolated from Khowai and Amtali, respectively. There were four species from Acaulospora, one from Clarideoglomus, two from Funneliformis, one from Gigaspora, seven from Glomus, two from Rhizophagus, and one from Sclerocystis. Ten species of AM fungi were commonly found in both the sites (Table 4).

\section{DISCUSSION}

The study involves mycorrhizal colonization status in plants from home gardens. Dual colonization was reported earlier in other ecosystem from this region [33]. AM fungal colonization was higher than DSE fungal colonization which is in agreement with an earlier report [33]. The colonization between the sites

Table 2: Soil physicochemical characteristics of soils of two home gardens of Tripura.

\begin{tabular}{lccccccc} 
Site & Sand & Silt & Clay & pH & EC $\left(\mathbf{c S ~ c m}^{-1}\right)$ & $\begin{array}{c}\text { Organic } \\
\text { carbon (\%) }\end{array}$ & $\begin{array}{c}\text { Available } \\
\text { phosphorus } \\
\text { (\%) }\end{array}$ \\
Khowai & 73.64 & 12.15 & 14.19 & $5.14 \pm 0.01$ & $148.00 \pm 1.15$ & $0.99 \pm 0.003$ & $3.68 \pm 0.05$ \\
Amtali & 78.03 & 14.36 & 7.61 & $5.58 \pm 0.01$ & $128.67 \pm 4.37$ & $0.73 \pm 0.002$ & $1.36 \pm 0.02$ \\
$t$ value & - & - & - & 890.274 & 128.171 & 33.953 & 70.726 \\
$p<$ & - & - & - & 0.001 & 0.001 & 0.01 & 0.01 \\
\hline
\end{tabular}
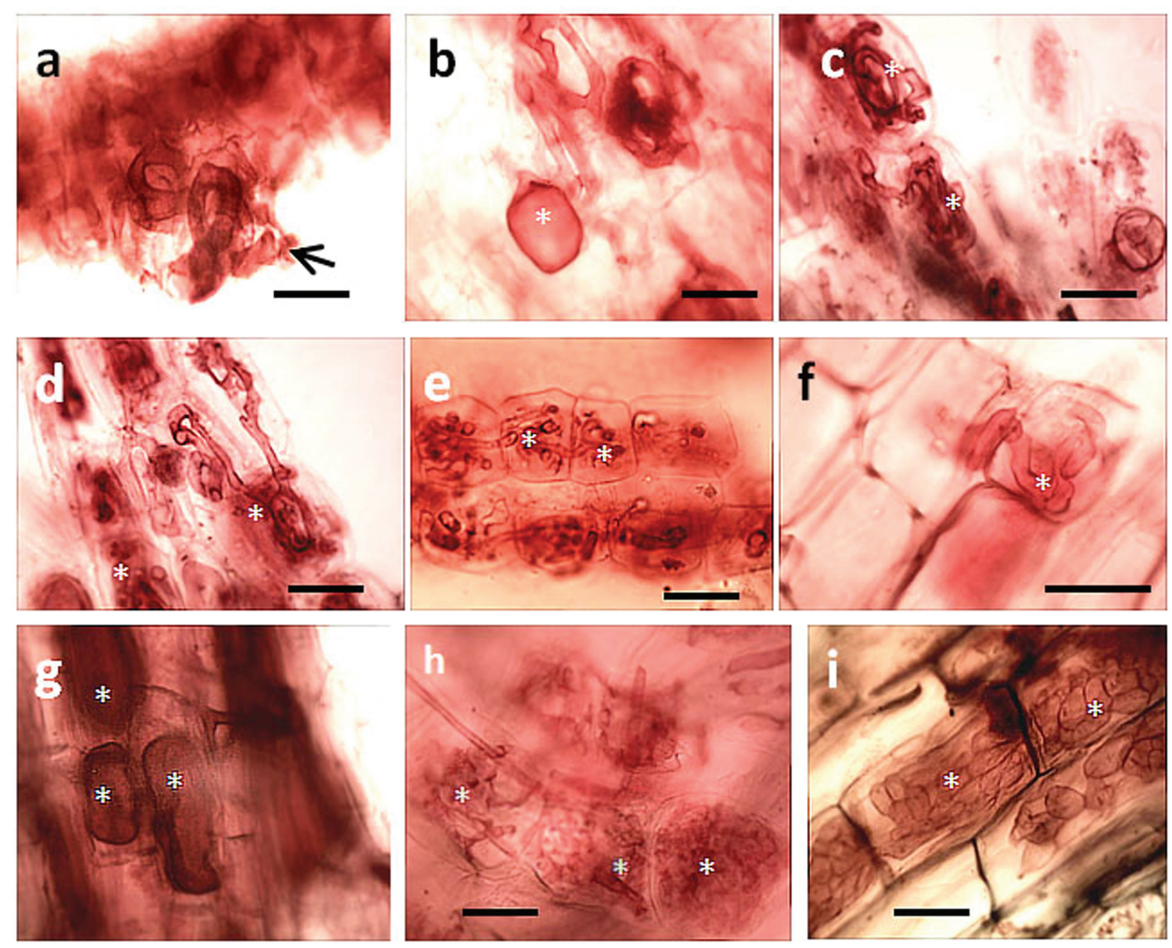

Figure 1: Arbuscular mycorrhizal fungal colonization of plants from the home garden. (a) hyphal appressorium entering the epidermal layer of $A$. comosus, (b) vesicles in the root segment of A. comosus, (c) cell-to-cell hyphal coiling in root of Annona squamosa, (d) arbusculate coils in the root of $A$. squamosa, (e) arbusculate coils in root portion of A. squamosa, (f) hyphal coil in root portion of S. melongena, (g) vesicles in the root portion of S. cumini, (h) arbusculate coils in the root segment of S. cumini, and (i) hyphal coils in the root cells of C. annuum (Scale bar: a, c, d, e, and $\mathrm{g}=200 \mu \mathrm{m}$; b, f, $\mathrm{h}$ and $\mathrm{i}=100 \mu \mathrm{m})$. 

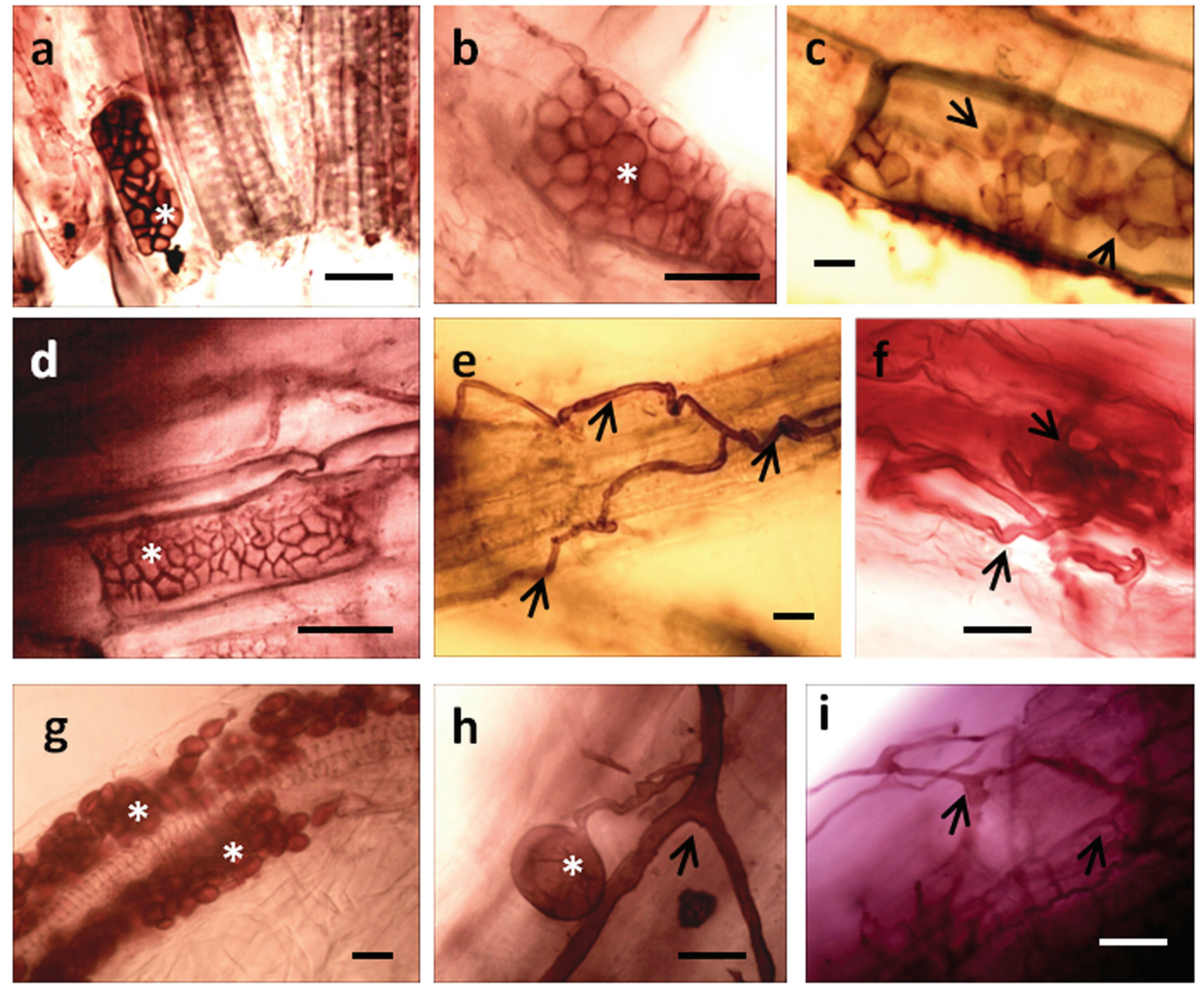

Figure 2: Endophytic fungal association in plants of the home garden. (a) Microsclerotia in the root of S. pinnata,

(b) microsclerotia in the root segment of A. comosus, (c) intracellular septate hyphae in root of S. melongena, (d) root segment of C. pepo showing microsclerotia, (e) septate hyphae entering the root of C. pepo, (f) intercellular septate hyphae in the root of $C$. annuum,

(g) microsclerotia in the root of A. tricolor, (h) spore-like (asterisk) and aseptate hyphae (arrow) attached to the root of A. tricolor, and

(i) extraradical aseptate hyphae attached to the root of $A$. tricolor (Scale bar: $\mathrm{b}=50 \mu \mathrm{m}$; $\mathrm{a}, \mathrm{e}, \mathrm{f}$, and i $=100 \mu \mathrm{m}$; $\mathrm{d}$ and $\mathrm{h}=150 \mu \mathrm{m}$; $\mathrm{c}$ and $\mathrm{g}=200 \mu \mathrm{m})$.

of most of the plants exhibited no significant differences. This may be due to the same climate both the places share although there are significant differences between the soil properties. Amaranthus tricolor was found to be colonized by endophyte as there is no record of the presence of arbuscules in most members of Amaranthaceae which is in accord with the previous study [33].

The AM fungal colonization in roots of A. comosus was much higher than the earlier study [34]. Sarwade et al. [35] recorded a higher percentage of AM fungal colonization in C. annuum. The colonization of AM fungi in $C$. annuum falls within the range of Tanwar et al. [36]. AM fungal colonization in Cucurbita pepo was higher than recorded earlier [37]. AM and DSE fungal colonization in $S$. melongena was lower than the previous study [38]. This present study of AM fungal colonization percentage in S. melongena was within the range of earlier study [39]. AM fungal colonization in Syzygium cumini was higher than the study of Kumar et al. [40].
Despite the importance of AM fungi, knowledge of the diversity and ecology of these ubiquitous and important soil fungi is limited globally [41]. Total number of AM fungal spores isolated from the rhizosphere of home garden plants indicates that the spore density and species richness were maximum in Khowai than Amtali. The community of AM fungal species in the rhizosphere may vary with host species [42]. AM fungal species composition and spore density are highly variable and influenced by plant characteristics and a number of edaphic factors such as soil $\mathrm{pH}$ and soil moisture content [43]. It implies that AM fungal colonization may be affected by the broad interactions of several factors, such as the factors inherent to the host plant, climatic and edaphic factors, and effects of the soil community [44].

The probable reason for the prevalence of Glomus may be due to Glomus has different $\mathrm{pH}$ preferences [45] and Acaulospora are frequently isolated from acidic soils [46]. Gigaspora prevails in high sand content [47]. The dominance of Glomus was also reported from this region $[23,25,33,48]$. 
Table 3: The extent of arbuscular mycorrhizal and dark septate endophyte fungal colonization of plants growing in home gardens of Tripura.

\begin{tabular}{|c|c|c|c|c|c|c|c|c|}
\hline \multirow{2}{*}{ Plants } & \multicolumn{4}{|c|}{ Khowai } & \multicolumn{4}{|c|}{ Amtali } \\
\hline & \%RLA & $\% R L V$ & $\%$ RLH & $\%$ RLDSE & $\%$ RLA & $\%$ RLV & $\%$ RLH & $\%$ RLDSE \\
\hline A. tricolor & $0.00 \pm 0.00$ & $14.69 \pm 2.08 \mathrm{a}$ & $37.97 \pm 1.94 \mathrm{a}$ & $44.39 \pm 2.25 \mathrm{a}$ & $0.00 \pm 0.00$ & $9.91 \pm 2.04 \mathrm{a}$ & $32.79 \pm 2.80 \mathrm{a}$ & $38.77 \pm 2.99 a$ \\
\hline A. comosus & $4.50 \pm 1.57 \mathrm{a}$ & $12.28 \pm 2.10 \mathrm{a}$ & $50.11 \pm 2.61 b$ & $31.15 \pm 1.73 b$ & $3.09 \pm 1.37 \mathrm{a}$ & $14.23 \pm 2.03 a$ & $50.53 \pm 3.03 b$ & $30.43 \pm 2.86 b$ \\
\hline A. squamosal & $21.54 \pm 2.71 b$ & $10.70 \pm 1.47 \mathrm{a}$ & $59.53 \pm 2.46 \mathrm{c}$ & $31.75 \pm 2.39 b$ & $32.64 \pm 2.37 b$ & $12.78 \pm 1.81 \mathrm{a}$ & $58.68 \pm 3.24 \mathrm{c}$ & $26.42 \pm 1.54 \mathrm{~b}$ \\
\hline C. annuum & $26.12 \pm 3.60 \mathrm{~b}$ & $29.71 \pm 2.43 b$ & $74.00 \pm 2.10 \mathrm{~d}$ & $20.59 \pm 1.97 \mathrm{~d}$ & $51.10 \pm 2.19 \mathrm{c}$ & $10.06 \pm 1.61 \mathrm{a}$ & $72.94 \pm 1.61 d$ & $21.64 \pm 1.11 b c$ \\
\hline C. реро & $38.74 \pm 3.04 \mathrm{c}$ & $9.07 \pm 1.50 \mathrm{c}$ & $68.89 \pm 1.88 \mathrm{~d}$ & $27.94 \pm 2.07 \mathrm{~b}$ & $40.95 \pm 3.25 d$ & $11.30 \pm 1.46 a$ & $61.80 \pm 2.81 \mathrm{c}$ & $22.16 \pm 1.87 b c$ \\
\hline S. melongena & $27.59 \pm 1.55 b$ & $6.56 \pm 1.13 \mathrm{~d}$ & $70.82 \pm 2.10 \mathrm{~d}$ & $17.44 \pm 2.22 \mathrm{~d}$ & $51.03 \pm 1.96 \mathrm{c}$ & $9.27 \pm 1.18 \mathrm{a}$ & $70.84 \pm 1.43 d$ & $20.35 \pm 1.94 \mathrm{c}$ \\
\hline S. pinnata & $41.03 \pm 3.47 \mathrm{c}$ & $10.27 \pm 1.70 \mathrm{a}$ & $61.53 \pm 3.11 \mathrm{c}$ & $23.97 \pm 2.55 \mathrm{~d}$ & $44.60 \pm 3.11 \mathrm{~d}$ & $6.04 \pm 1.44 b$ & $61.32 \pm 3.42 \mathrm{c}$ & $19.15 \pm 2.35 \mathrm{c}$ \\
\hline S. cumini & $47.82 \pm 2.25 \mathrm{c}$ & $10.24 \pm 1.39 \mathrm{a}$ & $69.84 \pm 1.79 d$ & $21.25 \pm 1.49 \mathrm{~d}$ & $31.95 \pm 1.49 b$ & $9.25 \pm 1.82 \mathrm{a}$ & $61.01 \pm 1.85 \mathrm{c}$ & $26.92 \pm 1.72 b$ \\
\hline
\end{tabular}

$\%$ RLA, \%RLV, \% RLH, and \%RLDSE percent root length with arbuscules, vesicles, hyphae, and dark septate endophyte, respectively.

Different alphabets differ significantly at $p<0.05$.

Table 4: Composition of arbuscular mycorrhizal fungal species from home gardens.

\begin{tabular}{|c|c|c|}
\hline AM fungal spore morphotype & Khowai & Amtali \\
\hline Acaulospora cavernata Błaszk. & - & - \\
\hline Acaulospora foveata Trappe \& Janos & + & + \\
\hline Acaulospora sp. 1 & - & + \\
\hline Acaulospora sp. 2 & + & - \\
\hline Clarideoglomus sp. 1 & + & + \\
\hline Funneliformis sp. 1 & + & - \\
\hline Funneliformis sp. 2 & + & - \\
\hline Gigaspora sp. 1 & - & + \\
\hline Glomus tortuosum Schenck \& Sm. & + & - \\
\hline Glomus macrocarpum Tul. \& Tul. & + & + \\
\hline Glomus sp. 1 & + & + \\
\hline Glomus sp. 2 & + & + \\
\hline Glomus sp. 3 & + & + \\
\hline Glomus sp. 4 & + & + \\
\hline Glomus sp. 5 & + & + \\
\hline $\begin{array}{l}\text { Rhizophagus irregulare (Błaszk., } \\
\text { Wubet, Renker \& Buscot) Walker \& } \\
\text { Schüßler }\end{array}$ & + & + \\
\hline $\begin{array}{l}\text { Rhizophagus intraradices (Schenck \& } \\
\text { Sm.) Walker \& Schüßler }\end{array}$ & + & + \\
\hline Sclerocystis sinuosa Gerd. \& Bakshi & - & + \\
\hline Species richness & 14.00 & 13.00 \\
\hline Spore density $/ 50 \mathrm{~g}$ soil & $142.67 \pm 6.39$ & $88.33 \pm 4.67$ \\
\hline
\end{tabular}

$+=$ Present; $-=$ Absent.

\section{CONCLUSION}

The study reveals the existence of a well-established relationship between plants and mycorrhizal fungi with regard to suitable colonization and robust composition of AM fungi. Further work should be directed to evaluate these essential native fungi on the growth of these plants. This study is also an effort to create awareness among the small scale farmers that the efficiency of these mycobiota which can be harnessed for long-term applications.

\section{ACKNOWLEDGMENTS}

The authors are thankful to the Head, Department of Botany, Tripura University, for providing the laboratory facilities.
$\mathrm{KC}$ is grateful to the Department of Science and Technology, Government of India, for the INSPIRE fellowship.

\section{CONFLICTS OF INTEREST}

There are no conflicts of interest.

\section{REFERENCES}

1. Schußler A, Schwarzott D, Walker C. A new fungal phylum, the Glomeromycota: phylogeny and evolution. Mycol Res 2001;105:1413-21.

2. Smith SE, Read DJ. Mycorrhizal symbiosis. 2nd edition, Academic, San Diego, CA, 1997.

3. Smith SE, Smith FA, Jakobsen I. Mycorrhizal fungi can dominate phosphate supply to plants irrespective of growth responses. Plant Physiol 2003;133:16-20.

4. Al-Karaki GN. Benefit, cost and water-user efficiency of arbuscular mycorrhizal durum wheat grown under drought stress. Mycorrhiza 1998;8:41-5.

5. Aroca R, Porcel R, Ruiz-Lozano JM. How does arbuscular mycorrhizal symbiosis regulate root hydraulic properties and plasma membrane aquaporins in Phaseolus vulgaris under drought, cold or salinity stresses? New Phytol 2007;173:808-16.

6. Borowicz VA. Do arbuscular mycorrhizal fungi alter plant-pathogen relations? Ecology, 2001;82:3057-68.

7. Jumpponen A. Dark septate endophytes - are they mycorrhizal? Mycorrhiza, 2001;11:207-11.

8. Peterson RL, Massicotte HB, Melville LH. Mycorrhizas: anatomy and cell biology. National Research Council of Canada, Ottawa, Ontario, Canada, 2004.

9. Jumpponen A, Trappe JM. Dark septate endophytes: a review of facultative biotrophic root-colonizing fungi. New Phytol, 1998; 140:295-310.

10. Das P, Kayang H. Association of dark septate endophytes and arbuscular mycorrhizal fungi in potato under field conditions in the northeast region of India. Mycology, 2010;1(3):171-8.

11. Kumar BM, Nair PKR. The enigma of tropical homegardens. Agroforest Syst 2004;61:135-52.

12. Salako VK, Fandohan B, Kassa B, Assogbadjo AE, Idohou AFR, Gbedomon RC, et al. Home gardens: an assessment of their biodiversity and potential contribution to conservation of threatened species and crop wild relatives in Benin. Genetic Resour Crop Evol 2014;61:313-30.

13. Galluzzi G, Eyzaguirre P, Negri V. Home gardens: Neglected hotspots of agro-biodiversity and cultural diversity. Biodiver Conserv 2010;19:3635-54.

14. Reyes-Garcia V, Aceituno L, Vila S, Calvet-Mir L, Garnatje T, Jesch $\mathrm{A}$, et al. Home gardens in three mountain regions of the Iberian 
Peninsula: description, motivation for gardening, and gross financial benefits. J Sustain Agric 2012;36:249-70.

15. Zhao ZW, Wang GH, Yang L. Biodiversity of arbuscular mycorrhizal fungi in tropical rainforests of Xishuangbanna, southwest China. Fungal Divers 2003;13:233-42.

16. Moreira M, Baretta D, Tsai SM, Gomes-da-Costa SM, Cardoso EJBN. Biodiversity and distribution of arbuscular mycorrhizal fungi in Araucaria angustifolia forest. Sci Agricola 2007;64(4):393-9.

17. Bonfim JA, Vasconcellos RLF, Gumiere T, Mescolotti DLC, Oehl F, Cardoso EJBN. Diversity of arbuscular mycorrhizal fungi in a Brazilian Atlantic forest toposequence. Microbial Ecol 2016;71:16477.

18. Liu Y, He L, An L, Helgason T, Feng H. Arbuscular mycorrhizal dynamics in a chronosequence of Caragana korshinskii plantations. FEMS Microbiol Ecol 2009;67:81-92.

19. Gao QM, Guo LD. A comparative study of arbuscular mycorrhizal fungi in forest, grassland and cropland in the Tibetan Plateau, China. Mycology 2010;1(3):163-70.

20. Das P, Kayang H. Mycorrhizal colonization and distribution of arbuscular mycorrhizal fungi associated with Michelia champaca L. under plantation system in northeast India. J Forest Res 2010;21(2):137-42.

21. Arias RM, Heredia-Abarca G, Sosa VJ, Fuentes-Ramırez LE. Diversity and abundance of arbuscular mycorrhizal fungi spores under different coffee production systems and in a tropical montane cloud forest patch in Veracruz, Mexico. Agroforest Syst 2012;85:179-93.

22. Liu W, Zhang Y, Jiang S, Deng Y, Christie P, Murray PJ, et al, Arbuscular mycorrhizal fungi in soil and roots respond differently to phosphorus inputs in an intensively managed calcareous agricultural soil. Sci Rep 2016;6:24902.

23. Chakraborty K, Sinha S, Debnath A, Roy Das A, Saha AK, Das P. Arbuscular mycorrhizal fungal colonization in three different age groups of rubber plantations in Tripura, North-East India. Plant Pathol Quarant 2016;6(2):122-31.

24. Bordoloi A, Nath PC, Shukla AK. Distribution of arbuscular mycorrhizal fungi associated with different land use systems of Arunachal Pradesh of Eastern Himalayan region. World J Microbiol Biotechnol 2015;31:1587-93.

25. Sinha S, Chakraborty K, Saha AK, Das P. Mycorrhizal colonization in plants from selected home garden of Tripura. J Mycopathol Res 2016;54(3):349-53.

26. Bouyoucos GK. Estimation of colloidal materials in soils. Science 1926;64:632.

27. Anderson JM, Ingram JSI. Tropical soil biology and fertility: a handbook of methods. CAB International, Wallingford, UK, 1993.

28. Allen SE, Grimshaw HM, Parkinson JA, Quaramby C. Chemical analysis of ecological materials. Blackwell, Oxford, 1974.

29. Das P, Kayang H. Stamp pad ink, an effective stain for observing arbuscular mycorrhizal structure in roots. World J Agric Sci 2008;4:58-60.

30. McGonigle TP, Miller MH, Evans DG, Fairchild GL, Swan JA. A method which gives an objective measure of colonization of roots by vesicular-arbuscular mycorrhizal fungi. New Phytol 1990;115:495501.

31. Gerdemann JW, Nicholson TH. Spores of mycorrhizal endogones species extracted from soil by wet sieving and decanting. Transact $\mathrm{Br}$ Mycol Soc 1963;46:235-44.

32. Koske RE, Tessier B. A convenient, permanent slide mounting medium. Mycol Soc Am Newsletter 1983;34:59.
33. Debnath A, Karmakar P, Debnath S, Roy Das A, Saha AK, Das P. Arbuscular mycorrhizal and dark septate endophyte fungal association in some plants of Tripura, North-East India. Curr Res Environ Appl Mycol 2015;5(4):398-407.

34. Rodríguez-Romero AS, Azcón R, Jaizme-Vega MDC. Early mycorrhization of two tropical crops, papaya (Carica papaya L.) and pineapple (Ananas comosus (L.) Merr.), reduces the necessity of $\mathrm{P}$ fertilization during the nursery stage. Fruits 2011;66:3-10.

35. Sarwade PP, Chandanshive SS, Kanade MB, Ambuse MG, Bhale UN Growth effect of Capsicum annum var. Jwala plants inoculated with Glomus fasciculentum and Trichoderma species. Int Multidiscip Res J 2011;1(12):13-6.

36. Tanwar A, Aggarwal A, Kadian N, Gupta A. Arbuscular mycorrhizal inoculation and super phosphate application influence plant growth and yield of Capsicum annuum. J Soil Sci Plant Nutr 2013;13(1):5566.

37. Sensoy S, Bicer S, Unsal H. Arbuscular mycorrhizal fungi affect seedling growth of melon hybrid cultivars. Int J Agric Biol 2013;15:392-4.

38. Muthukumar T, Senthilkumar M, Rajangam M, Udaiyan K. Arbuscular mycorrhizal morphology and dark septate fungal association in medicinal and aromatic plants of Western Ghats, Southern India. Mycorrhiza 2006;17:11-24.

39. Patale SW. Screening of brinjal rhizosphere soil for assessment of AM Fungi. Int J Adv Multidiscip Res 2016;3(1):74-7.

40. Kumar R, Tapwal A, Jaime A, da Silva T, Pandey S, Borah D. Diversity of arbuscular mycorrhizal fungi associated in a mixed natural forest of Jeypore, Assam. Biorem Biodiv Bioavail 2013;7(1):91-3.

41. May TW. Documenting the fungal biodiversity of Australasia: from 1800 to 2000 and beyond. Aust Syst Bot 2001;14:329-56.

42. McGonigle TP, Fitter AH. Ecological specificity of vesiculararbuscular mycorrhizal associations. Mycol Res 1990;94:120-2.

43. Boddington CL, Dodd JC. Evidence that differences in phosphate metabolism in mycorrhizae formed by species of Glomus and Gigaspora might be related to their life cycle strategies. New Phytol 1999;142:531-8.

44. Moreira M, Baretta D, Tsai SM, Cardoso EJBN. Spore density and root colonization by arbuscular mycorrhizal fungi in preserved or disturbed Araucaria angustifolia (Bert.) O. Ktze. ecosystems. Sci Agric 2006;63:380-5.

45. Wang CL, Tschen JSM, Wang CL. Factors on the spore germination of arbuscular mycorrhizal fungi, Glomus spp. Fungal Sci 1997;12:3-4.

46. Morton JB. Three new species of Acaulospora (Endogonaceae) from high-aluminium, low $\mathrm{pH}$ soils in West Virginia. Mycologia 1986;78:641-8.

47. Lee PJ, Koske RE. Gigaspora gigantea: Seasonal, abundance and ageing of spores in a sand dune. Mycol Res 1994;98:453-7.

48. Talapatra K, Das A, Das AR, Saha AK, Das P. Mycorrhizal colonization of understorey plants growing in rubber plantation of Tripura in Northeast India. Mycorrhiza News 2015;27(2):2-8.

\section{How to cite this article:}

Chakraborty K, Debnath A, Das AR, Saha AR, Das P. Rootfungal associations in plants from home gardens of Tripura, Northeast India. J Appl Biol Biotech 2019;7(05):25-30. 